\title{
Sverre Raffnsøe
}

\section{Ansvarlighedens og samvittighedens herkomst ifølge Nietzsche}

\section{Indledning}

Det er en kendt sag at Nietzsche ikke betragter vores opfattelse af godt og ondt som en naturgiven selvfølgelighed, men i stedet ser den som resultatet af en historisk proces. I I. afhandling i hovedværket Zur Genealogie der Moral, forfattet på blot tre uger i sensommeren 1887, fremstiller han således vores nuværende opfattelse som resultatet af en "slaveopstand i moralen", der byttede om på det tidligere gode (= det udmærkede, det fornemme) og slette (= det almindelige, det gemene) for at gøre plads til moralen, som den nu foreligger, altså en moral med godt (= det tidligere slette) og ondt (= det tidligere gode). I forhold til en forhistorisk "aristokratisk værdiligning" der lød "god $=$ fornem $=$ mægtig $=$ smuk $=$ lykkelig $=$ gudselsket", foregik der ifølge Nietzsche en "radikal omvendelse af værdier", hvor "alene de elendige", "de fattige, afmægtige, nedrige" kunne komme i betragtning som "de gode", men nu i betydningen 'moralsk gode' (jvf. Zur Genealogie der Moral, I. afh. afs. 7). Den moralske godhed er således fra første færd at forstå som en afstandstagen, eller et nej, til en tidligere gældende moralitet, og vores opfattelse af en eviggyldig moral har altså sin egen forhistorie eller herkomst, som Nietzsche ønsker at blotlægge for at kunne stille spørgsmålstegn ved dens selvfølgelighed. Med en revolte i de lavereståendes rækker søger han at forklare, hvordan der er opstået en moral hvor man fordømmer og lægger afstand til en tidligere aristokratisk kulturs livsudfoldelse, der angiveligt er foregået på bekostning af andre, for i stedet at hylde mere blivende værdier som næstekærlighed og humanitet. Ifølge Nietzsche hænger denne revolte imidlertid sammen med en bestemt ressentimentsreaktion: Når den aristokratiske værdisætning har karakter af en aktivitet, der uundgåeligt udfolder sig på bekostning af noget andet, kommer de gemene eller svage uomgængeligt til at lide og føle afmagt. De er nemlig i aristokratiets sociale verden ikke i stand til at komme ud af denne ubehagelige situation ved en umiddelbar aktivitet, da de hverken kan udmærke sig eller gøre sig gældende her. Derfor forgiftes deres tilværelse, og det afføder en res- 
sentimentssfølelse, idet de igen og igen (ressentiment. fr. af latin re-sentire, at genfole) føler det samme. Den lidelse de ikke kan komme af med, bliver ved at dukke op, og det fører til det nag, der til sidst afstedkommer slaveopstanden i moralen.

Alt dette - slaveopstanden i moralen, diskvalificeringen af det aristokratiske samfund, ressentimentsreaktionen - er efterhånden kendte temaer i receptionen og genfremstillingen af Nietzsches tænkning. Det er imidlertid mindre kendt, hvordan Nietzsche i II. afhandling i Zur Genealogie der Moral undersøger foreteelser som ansvarlighed og samvittighed på tilsvarende vis. Heller ikke disse kan nemlig anskues som de urfænomener eller moralske fænomener de som regel agtes for, men er tværtimod, sammen med den kultur de er blevet forfinet i samspil med, fænomener der kan dateres tilbage til en præmoralsk forhistorie som kun bevidnes indirekte igennem de overleverede historiske kilder. Og denne forhistorie rummer ifølge Nietzsche "menneskets egentlige arbejde med sig selv i menneskehedens længste tider, hele dette forbistoriske arbejde $[\ldots]$ hvor meget det end rummer af hårdhed, tyranni, stupiditet og idioti” (II. afh., afs. 2). Forhistorien er altså, i hvert fald i nogle henseender, mere betydningsfuld end historien. Igennem denne forhistorie ophører mennesket nemlig først med at være dyr og bliver menneske i egentlig forstand.

Nærværende artikel sætter sig derfor for at skitsere Nietzsches tanker om ansvarlighedens herkomst i sin signifikante forhistoriske sammenhæng, således som han først og fremmest skildrer den i II. afhandling af Zur Genealogie der Moral. Samtidig viser jeg hvordan Nietzsche mener at ansvarligheden må betragtes som beslægtet med fænomener som straf, ret og skyld. Men det bliver også væsentligt at vise at ansvarligheden, der ifølge Nietzsche til at begynde med har haft et udadrettet og eksternt virke, efterhånden ændrede sig for at blive internaliseret i mennesket $i$ form af den samvittighed, der igennem historien har haft en bemærkelsesværdig tendens til at blive til en darlig samvittighed. Det er således også artiklens formål at fremstille baggrunden for et fænomen, den dårlige samvittighed, der stadig gør sig gældende og virker ind på vores nuværende kultur, ganske vist under nye former. Dette vil jeg komme tilbage til hen imod slutningen.

\section{Sædvanernes sædelighed}

Ansvarligheden og samvittighedens forhistorie er ifølge Nietzsche karakteriseret af den sadvanernes sadelighed (Sittlichkeit der Sitten), som han omtaler i Morgenröte (1881). Her bestemmes sædvanerne som "de hævdvundne levemåder" hvis herkomst skyldes "en højere autoritet hvilken man adlyder, ikke fordi den befaler os det nyttige, men derimod fordi den befaler [weil sie befiehlt] [...]. 
Det er frygten [...] for en ubegribelig, ubestemmelig magt, for noget mere end det blot personlige" (I. bog, afs. 9; fremhævelse tilføjet). Den forhistoriske kultur er altså karakteriseret af en overleveret sædelighed, af overleverede normer, som kræver at man adlyder dem, ikke fordi man selv ønsker det, eller man selv kan indse det fornuftige $i$ at adlyde dem, men ganske simpelt fordi de er overleverede. Sædvanen kræver, at man adlyder, og her adlyder man vel at mærke ikke ved at henvise til en anden og højere instans, men ganske simpelt "weil sie befielt". Sædvanen kan konkret være forskellig af indhold eller udformning, og der kan også være tale om forskellige sædvaner; men fælles for dem alle er at de stiller med et krav om at blive adlydt, og det er dette fællesskab Nietzsche vil angive med sit begreb om "Sittlichkeit der Sitten". Sædelighed er således "lydighed mod sædvaner" (Gehorsam gegen Sitten) (jvf. ibid.).

Der er imidlertid i sædvanernes sædelighed tale om to niveauer: For det første selve de sadvaner man adlyder; disse varierer mellem de forskellige forhistoriske samfund, de er kontingente eller tilfældige, bornerte og endda af og til absurde eller afsindige. For det andet det faktum at man overhovedet viser lydighed mod sadvanerne; det at man adlyder loven, fordi den er lov; den simple lydighed. På den ene side er der tale om en bestemt samfundsordens eller en bestemt institutions, f.eks. en stats eller kirkes, tryk og tvang over for enkeltindividet. På den anden side er der tale om det forhold, at samfundsordenen og menneskearten overhovedet udøver tvang over for individet. Kravet om lydighed er et fællestræk ved de forskellige former for sædvanelove, et fællestræk ved hele den forhistoriske kultur der overskrider det kontingente.

Med sit begreb om sædvanernenes sædelighed prøver Nietzsche at angive en kultur for historien, et generelt kulturelt niveau der er forudsætningen for, at en historie i egentlig forstand overhovedet kan opstå. Denne kultur har ifølge Nietzsche karakter af en tamningsproces, en dressur eller en opdrætning. Her finder en tæmning af mennesket sted, der bevirker, at det ikke bare følger sin egen natur og sine indskydelser. "Die Sittlichkeit der Sitte" byder eller forlanger således at "den enkelte skal (op)ofre sig" (ibid.). Rovdyret "menneske" tæmmes eller opdrættes, således at det holder op med at være et rovdyr og bliver noget andet - menneske i egentlig forstand, menneske uden anførselstegn (jvf. Zur Genealogie der Moral, II. afh., afs. 11). Først igennem den forhistoriske kultiverings- og kulturaliseringsproces bliver mennesket til. For til vores begreb om mennesket hører, at det kan bøje sig for eller adlyde noget, der er større end det selv. Mennesket er ifølge Nietzsche ikke noget naturvæsen, men et kulturvæsen. Det er et væsen der har lært ikke bare at følge sine naturlige drifter, men at bøje sig for eller følge regler. 


\section{Ansvarlighed og fortrægning}

Allerede i den førkulturelle sædelighed kan mennesket således drages til ansvar. Mennesket er hele tiden forpligtet på forskellige sædvanelove og må stå til ansvar over for dem. I denne førhistoriske 'socialisationsproces' lærer menneskedyret præcist hvornår sædvaneloven overskrides. Transgressionerne markeres nemlig hver eneste gang. Men ved på denne måde at blive tvunget til at stå til ansvar over for de forskellige sædvanelove, tilføjes mennesket en generel egenskab: det lærer sig ansvarlighed.

At sædeligheden kan dominere mennesket, forudsætter imidlertid at det kan dominere sig selv og sin omverden. Hvis det skal vise sig som et ansvarligt væsen, forudsætter det at ydre påvirkninger og indre indskydelser ikke bare bestemmer, hvordan det opfører sig, eller hvad det gør. Derfor kan Nietzsche bestemme "ansvarlighed" (Verantwortlichkeit) som "magt over sig selv og skæbnens tilskikkelser [Macht über sich und das Geschick]" (II. afh., afs. 11), da ansvarlighed forudsætter, at mennesket på den ene side kan dominere eller styre sig selv og sine indskydelser, men at det også på den anden side kan dominere de ydre påvirkninger. Ansvarlighed forudsætter altså selvbestemmelse over ydre såvel som indre tvang, og det vil sige at ansvarlighed forudsætter både beherskelse og regulering. - I freudianske termer kunne man sige, at ansvarligheden forudsætter at der installeres stærke og bevidste sekundærprocesser der kan beherske primærprocesserne og deres ubestandighed. Sammenligningen holder i hvert fald et stykke af vejen. Også for Nietzsche er sædeligheden og ansvarligheden nemlig en overbygning på og en fortrængning af en mere oprindelig natur - men vel at mærke ikke af selve den oprindelige 'natur'. Den natur Nietzsche taler om, ytrer sig som en 'Vergeßlichkeit", som en tendens til at glemme, til at omforme den oprindelige påvirkning ved at erstatte den med noget andet. Man kan sige, at der for Nietzsche finder en stadig fordøjelsesproces sted, der bestandigt indoptager eller omformer det givne og på den måde også til stadighed fortrænger det. I kraft af omformningen fortrænges det oprindeligt givne. I menneskets natur finder der således ifølge Nietzsche stadigt en ny værdisætning sted der ytrer sig som en aktiv fortrangning.

Kulturen gør sig her gældende som en punktvis standsning af denne proces. I kulturen og dens beherskelse af naturen underbindes naturens bestandige fortrængning af en tidligere natur. Kulturen er således nok fortrængning af naturen, men det er den kun for så vidt som den er en fortrængning af naturens egen stadige fortrangning, for så vidt som den beror på evnen til at huske, på hukommelse og erindring. Men her forstås hukommelse ikke som passiv opbevarelse; den består derimod $i$ en aktiv indsats for at fastholde, for ikke at glemme, for ikke at erstatte. Hukommelse er derfor aktiv vilje og intet reaktivt 
ressentiment (jvf. II. afh., afs. 1).

Den førhistoriske kultur tæmmede altså mennesket og gjorde det til et ansvarligt væsen, og herved forstår Nietzsche et væsen, der dels behersker sig selv og ydre påvirkninger, altså evner at sætte sig ud over dem eller at frigøre sig fra dem, og som dels behersker den naturlige tendens til at glemme, altså aktivt udfolder hukommelse. Et sådant væsen kan afgive lofter: det kan stille andre noget $\mathrm{i}$ udsigt, huske at det har stillet dem det i udsigt, og det kan endelig føle forpligtelse over for det som det har stillet i udsigt (jvf. II. afh., afs. 2). I den forhistoriske kultur er mennesket således blevet dannet $\mathrm{i}$ en form hvor det oprindelige rovdyr beherskes i en sådan grad at dets adfærd er blevet "regelmäßig und folglich berechenbar" (ibid.). Mennesket er blevet behersket og har lært at beherske sig selv i en sådan grad at man kan regne med det.

Ansvar er derfor ifølge Nietzsche i første omgang noget, som mennesket er sig bevidst, at det tager på sig. Det bliver hele tiden gjort opmærksomt på, at det har ansvaret for noget, og at det står til ansvar over for noget. Ansvaret opleves altså stadigvæk som relationer til noget eksternt. Men dressuren til ansvarlighed kan være lykkedes i den grad, at ansvarligheden slet ikke mere opleves. Da bliver ansvarlighed noget mennesket automatisk og intuitivt' tager på sig fordi det føler en indre trang til det. I dette tilfælde er kulturens ansvarlighed blevet integreret som en ny natur. Og det er her Nietzsches påstand at "samvittighed" ("Gewissen") er vores betegnelse for en ansvarlighed, der på denne måde er blevet vores anden natur. Den er da en ansvarlighed som vi instinktivt føler, en ansvarlighed som vi påtager os fordi vi ønsker at påtage os den. I vor samvittighed har den kulturelt dannede ansvarlighed altså taget skikkelse som vores 'anden natur'.

Med denne skildring af ansvarlighedens og samvittighedens forhistoriske herkomst prøver Nietzsche at vise, at de primært slet ikke er de moralske begreber, som vi senere har gjort dem til. Samvittighedens og ansvarlighedens herkomst og primære betydning er begge for-moralske. Ved at angive deres aner $i$ en forhistorisk sædernes sædelighed vil Nietzsche vise os, at vi ikke har lært at føle ansvar af humanitære grunde, eller fordi det er moralsk rigtigt. Vi har heller ikke lært at være samvittighedsfulde af hensyn til vores medmennesker eller af moralske grunde. Alle disse begrundelser og forklaringer er senere efterrationaliseringer. Ansvar og samvittighed er i stedet opstået relativt tidligt under trusler og igennem en bestemt afrettelsesproces der har forsøgt at forpligte os, og som til sidst har gjort den bestemte adfærd naturlig at vi forpligter os. 


\section{Straffens omtydning}

Denne skildring af ansvarets, samvittighedens og forpligtethedens genealogi er beslægtet med redegørelsen for straffens. - Og dette er oplysende i en tid, hvor straffens herkomst og dens formål ofte sammenblandes. Det hævdes ofte, f.eks., af de engelske moral-genealoger som Nietzsche tager afsæt $\mathrm{i}$ indledningen til Zur Genealogie der Moral, at straffens herkomst må afledes af dens formål. Straffen siges nemlig at have som formål enten at virke afskrækkende eller at give afløb for trang til hævn. Af disse formål afledes så straffens herkomst, og her er det så hævnen eller afskrækkelsen, der har konstitueret straffene og givet dem skikkelse.

Men Nietzsche hævder, at der er to forhold man må holde adskilte. Noget kan nemlig godt, på den ene side, være opstået inden for en bestemt sammenhæng og have sin bestemte funktion her, men så, på den anden side, være blevet udsat for en omtydning der gør det skikket til at tjene andre formål (jfr. II. afh., afs. 11). Og ansvaret, samvittigheden, forpligtetheden og straffen er alle eksempler på fænomener der har været udsat for en sådan omtolkningsog gentydningsproces. De bliver ifølge Nietzsche alle til i den kulturelle afretningsproces, men omtolkes så senere ved en ressentimentsreaktion til moralske fænomener.

I denne proces har straffen sin særegne og markante funktion idet menneskedyret afrettes på en ganske hård måde, nemlig vha. sanktioner og straffe, der tjener til at fremhjælpe det væsentlige element som hukommelsen er. Dette understreger Nietzsche bl.a. i den følgende passage: "Menneskehedens skikke fremtræder desto mere grufulde, jo dårligere dens hukommelse var; straffelovens hårdhed danner en særlig god målestok for i hvor høj grad den havde besvær med at besejre glemselen og gøre et par primitive forudsætninger for socialt samliv nærværende" (II. afh., afs. 2). Han peger i denne forbindelse på en række hårde straffe som endnu relativt sent var i brug $i$ Tyskland, og søger derved at vise hvilke hårde midler der skulle til for at tugte affekter og begær. Man stenede folk, lagde dem på hjul og stejle, lod dem rive i stykker af heste, smed dem i kogende olie, skar remme af deres hud. For at holde dyret $i$ ave var det nødvendigt at sætte en modbestialitet $i$ værk.

Overskridelser eller glemsel af ansvarligheden straffede man altså med udøvelse af vold, med et modangreb på den der viste sig uansvarlig ved at gå til angreb på forbudene. Vold er nemlig ifølge Nietzsche det eneste det førkulturelle menneskelige rovdyr kan forstå, og det gør mennesket fordi volden tilføjer det en smerte, som det må ønske at undgå. Smerten eller lidelsen hjælper på hukommelsen, da de markerer at det har optrådt uansvarligt: "»Hvordan skaffer man menneskedyret en hukommelse? Hvordan indpræger man [...] denne omkringvandrende glemsomhed noget sådant at det forbliver nærværende?«- 
Dette urgamle problem er ikke just blevet løst med nænsomme svar og midler; måske er intet mere frygteligt og uhyggeligt i hele menneskets forhistorie end dets mnemoteknik. [...] Kun hvad der ikke holder op med at gøre ondt, forbliver i hukommelsen" (II. afh., afs. 3). Kun gennem en vedholdende straffeprocedure, gennem en stadig udøvelse af vold og påføring af lidelse, har den tidlige civilisation og kultur altså kunnet minde mennesket om dets ansvarlighed. Lidelsen som det bestandigt blev påført, eller som det hele tiden måtte frygte at blive udsat for, forhindrede det $\mathrm{i}$ at glemme sine forpligtelser.

Derved bliver ansvarlighed, samvittighed og forpligtethed kategorier hvis herkomst kan henføres til et førmoralsk univers der er grundlæggende præget af vold. Og denne vold hæver de sig ikke op over; de er derimod gennemsyrede af den. Alt dette deler de imidlertid med kategorier som straf, ret, skyldighed og skyld. For ifølge Nietzsche straffede man oprindeligt, hverken fordi man anså forbryderen for at være et frit væsen, eller fordi man ville gøre "gerningsmanden ansvarlig for hans handling, altså ikke under den forudsætning at kun den skyldige burde straffes" (II. afh., afs. 4). I stedet straffede man alle, der overtrådte et forbud eller på anden måde trådte ved siden af. Straffen var simpelthen en gengældelse (Vergeltung) for en uorden eller overlast. Som oprundne af en førmoralsk verden er straffen og med den retten primært afrettelses- og voldsmidler der skal indskærpe eller afrette til ansvarlighed og socialitet.

Med dette udgangspunkt bliver resten af II. afhandling (afsnit 4-11) i Zur Genealogie der Moral en genealogisk genskrivning af strafferettens historie. Fra at have skildret hvordan menneskedyret disciplineres gennem forhistorien, går afhandlingen dermed i højere grad over til at beskæftige sig med disciplineringsmidlerne og deres forhistoriske herkomst. Nietzsche anfører således kort ved slutningen af afsnit 4, at når straffen ikke iværksættes for at drage forbryderen til ansvar, udføres den "snarere - sådan som forældre stadigvæk i dag straffer deres børn - pga. vrede over en tilføjet skade der imidlertid begrænses og modificeres af den forestilling at enhver skade har sin ækvivalent $i$ noget andet og virkeligt kan afbetales, om nødvendigt gennem skadevolderens smerte. - Hvorfra har denne urgamle idé om en ækvivalens mellem skade og smerte sin styrke? [...] - Fra kontraktforholdet mellem fordringshaver og skyldner, der på sin side igen viser tilbage til grundformerne køb, salg, bytte” (II. afh., afs. 4). Det sidste led er altså bytte- eller udvekslingsforholdet, i hvis rudiment straffens herkomst er at søge. Når noget der regnes for ækvivalent, er udvekslet i bytteforholdet, så er sagen afsluttet, og man kan gå hver til sit. Men det er jo ikke altid, at udligningen kan være fuldkommen, og i så fald opstår der et skyldighedsforhold som må udlignes ved senere lejlighed.

Dette skyldighedsforhold kan anses for at være den første relation mellem mennesker hvori der både er afhangighed og varighed. Det betegner en 
midlertidig mangel på ækvivalens, der må vente på sin udligning. Men skal mennesker kunne indgå i en sådan længerevarende social relation, må de kunne regne med hinanden, forudsige hinandens reaktioner og handlemønstre. Skyldneren må m.a.o. være i stand til både at love noget og at vise ansvarlighed, og det må tilgodehaveren kunne regne med. Til at sikre at det indbyrdes forhold kan være sådan, er straffen midlet. Den fastholder skyldneren på hans ansvar og viser en anden vej til at opnå ækvivalens, hvis skyldneren ikke holder sine løfter. Primært og forhistorisk er straffen altså et middel til at genoprette en ækvivalens, til at udligne et skyldforhold der ikke udlignes på den oprindeligt forudsatte måde. I straffen tager en person eller socialiteten sig betalt for en manglende betaling, så alt bliver udlignet og man kan begynde på en frisk. Man bringer på den måde sagen ud af verden og undgår derved at ende i nag og ressentiment. Kan straffen ikke bestå i at man indkasserer nogle af skyldnerens værdier, kan man tage sig betalt ved at man tilføjer ham smerte eller lidelse. Dette gør det forståeligt, at der allerede meget tidligt fandtes en ret nøje kodificering af hvilke af skyldnerens kropsdele tilgodehaveren kunne tilføje skade eller skære af for at holde sig skadesløs for en given tort. Udligningen sker i så fald ifølge "en henvisthed på og en ret til grusomhed" (II. afh. afs. 5).

En sådan grusomhed er vanskelig at acceptere $\mathrm{i}$ en senere moderne, moralsk og humanistisk tidsalder. Heri ser man nemlig livet an fra den afmægtigt lidendes synsvinkel. Derfor kommer den tilføjede lidelse til at fremstå som noget negativt, der bør fjernes. Men i forhistorien var den hverken noget, der kunne eller skulle fjernes. Den var en integreret del af livets fylde. At se på og tilføje lidelse var ifølge Nietzsche ligefremt en fornøjelse eller glæde, hvilket vi har svært ved at få øje på fordi: "det strider imod [...] hykleriet hos tamme husdyr (dvs. hos moderne mennesker) at prøve at forestille sig $\mathrm{i}$ hvor høj grad grusomheden udgjorde den store festglæde hos fortidens mennesker" (II. afh, afs. 6). - Nietzsche parodierer i den forbindelse Kant, fordi han taler om "die uninteressierte Bosheit" som en oprindelig værdi. Og han belægger det med, at det såmænd ikke er så længe siden, at fyrstelige højtider nærmest var utænkelige uden henrettelser, offentlig tortur eller måske en enkelt lille kætterbrænding. Den forhistoriske betalingsmåde at tilføje andre lidelse er ifølge Nietzsche uforståelig hvis ikke den har været forbundet med glæden ved at gøre det. Hvad man får igen ved at tilføje lidelse, er en glæde eller et behag ved at blive holdt skadesløs for en tort eller et ubehag man tidligere blev tilføjet. Balancen bliver genoprettet, og heri bunder den tidlige forestilling om retfærdighed. 


\section{Retfærdighed, lov, ret}

Ekevivalensen eller balancen er retfærdighedens ældste form, og dens naive kanon er: "alles kann abgezahlt werden". Her er der endnu slet ikke tale om nogen moralsk udligning, altså en udligning der må ske, fordi den er moralsk rigtig. Retfærdigheden er i stedet en praktisk udligning. Den er nødvendig, for at vi kan komme til forståelse med hinanden igen og starte på en frisk i en social situation, der er i balance: "Retfærdighed på dette første trin er den gode vilje til mellem nogenlunde lige mægtige at affinde sig med hinanden, til igen at »komme til forståelse« med hinanden gennem en udligning - og at tvinge de mindre mægtige til en indbyrdes udligning" (II. afh., afs. 8).

Forestillingen om social balance eller udligning beror på en forestilling om rimelighed, og sociale tilstande, der tenderer mod at konservere uligevægt, anses for urimelige. De underbinder nemlig den sociale udveksling og fører til uløselige konflikter mellem parter, der står i udveksling med hinanden. Afskaffes de ikke, fører de til ressentiment, nag og bitterhed. At udligne sådanne forestillinger er retfærdigt, fordi det kan bringe det sociale samvær til at glide igen. Den gensidige forståelse der er nødvendig hertil, betinges netop af at der er balance. Men bringes den i stand gennem en udligning, er man ikke derved havnet $i$ en stabil eller blivende tilstand. Balancen kan igen og igen bringes til at vakle, og da vil en ny udligning igen være et nødvendigt middel. Den sociale interaktion er altså forstået som noget, der er bevægeligt og uophørligt kan komme ud af balance, og derfor bestandigt igen må bringes tilbage i sin balance.

Et væsentligt middel til at sikre dette er imidlertid loven (das Gesetz) eller retten (das Recht). De indeholder nemlig den påbudte retfærdighed: "den imperativiske redegørelse for hvad der i det hele taget skal gælde [...] for tilladt og ret, og omvendt for forbudt og uret" (II. afh., afs. 11). Loven forsøger altså at bestemme det retfærdige og lægge åbent frem hvori det består. Den formaliserer derved, hvad der er at anse for en rimelig udveksling, og den fastholder og påtvinger os den retfærdighed, vi allerede på forhånd har bestemt os for. Som påbud sørger den derfor for en rimelig udveksling, og det gør den bl.a. ved at fastlægge de straffe der anses for nødvendige. Lov og ret afklarer hvad det rimelige i udvekslingen er, og de sikrer gennem påbud og, om nødvendigt, gennem straf bevidstheden herom. Således er loven og retten heller ikke mål i sig selv. De er midler, der skal sikre at socialiteten ikke fryser fast i nags- og ressentimentstilstande, men altid er i stand til at komme videre. Bliver de til mål i sig selv, bliver de livsfjendske, fordi de da vil hævde blot opnåede, foreløbige udligningstilstande som noget statisk. Og en sådan tilstand uden aktivitet og dynamik er død. Derfor skriver Nietzsche også at først "efter oprettelsen af loven" "gives der »ret« og »uret« (og ikke efter den krænkende akt). At tale om 
ret og uret $i$ sig selv savner enhver mening. I sig selv kan det at såre, udøve vold, udbytte, tilintetgøre naturligvis ikke være uret for så vidt som livet essentielt [...] fungerer sårende, voldsudøvende, udbyttende, tilintetgørende og slet ikke kan tænkes uden denne karakter. Man er endda nødt til at indrømme noget der er endnu mere betænkeligt: at »retstilstande« [...] altid kun kan være undtagelsestilstande forstået som delvise restriktioner på den egentlige livsvilje der er ude på magt, idet de som midler underordner sig livsviljens samlede formål: at skabe storre magtenheder. Forestiller man sig en suveræn og almen retsorden ikke som et middel i magtkompleksernes kamp, men derimod som et middel imod al kamp overhovedet [...], ville en sådan retsorden være et livsfjendtligt princip, ødelæggende og opløsende for mennesket, et attentat på menneskehedens fremtid, et tegn på træthed, en snigvej til intetheden" (II. afh., afs. 11).

Hermed vil Nietzsche imidlertid næppe sige, at alt er rå magt og at lov og ret blot er illusioner. Han vil snarere understrege, at refærdighed og lov opstår inden for bestemte livssammenhænge og har deres funktion her. Den udveksling der finder sted i lov og retfærdighed, muliggør at større sociale korporationer kan opstå, og på den måde virker de livsbekræftende. Men de kan ikke løsrives fra denne deres sammenhæng og gøres til ubetingede formål for livet som helhed uden at miste deres funktion og blive livsfjendske.

\section{Kulturel beherskelse versus ressentiment}

Via sin skildring af den forhistorie som Nietzsche mener at kunne ane igennem og bag ved vores historie, prøver han altså at påvise hvordan samvittighed, ansvarlighed og hukommelse har deres rødder i en (forhistorisk) kultur som har karakter af en opdragelse eller afretning til socialitet. Og sådan en kultur kan netop virke livsbekræftende, da den kulturelle beherskelse kan tjene som et middel til at forøge livsfylden eller til at højne livet. I forlængelse af disse bestemmelser kan Nietzsche også betragte sådanne fænomener, samvittighed, ansvarlighed, hukommelse, som størrelser der står i modsætning til ressentimentet. For "det aktive menneske der går til angreb og overgreb, står altid retfærdigheden hundrede skridt nærmere end det reaktive. [...] Det aggressive menneske har til alle tider som stærkere, modigere, fornemmere haft den bedre samvittighed på sin side: omvendt gætter man let hvem der har opfindelsen af »den dårlige samvittighed « på sin samvittighed - ressentiment-mennesket" (II. afh., afs. 11).

Ressentimentet står i modsætning til samvittighed og retfærdighed i ordenes forhistoriske betydning. Det er ikke en følelse, der som disse søger udligning, men en følelse af nag der kræver overkompensation i forhold til den uret, man er blevet tilføjet. Det er altså netop ikke ressentimentet, der opfinder 
samvittigheden som instans, der gør os tilbøjelige til at opfylde den udligning, som vi lover. Det er i stedet ressentimentet, der efterfolgende omtolker den 'gode' samvittighed, tilfredsstillelsen ved at holde hvad man lover, til den sygelige og utilfredsstillende dårlige samvittighed. Samvittigheden i dens oprindelige betydning står altså ifølge Nietzsche i modsætning til dårlig samvittighed; de har simpelthen hver deres herkomst.

Gennem sin beskæftigelse med vores historiske kultur sådan som den er overleveret, prøver Nietzsche altså at fremlæse en 'forudgående' forbistorisk kultur. Og den centrale 'begivenhed' i denne forhistorie er det forhold at der finder en disciplinering eller afretning af dyret menneske sted. At denne afretning finder sted er nemlig en forudsætning for, at historien som sådan kan opstå; det er netop først afretningen der gør mennesket til noget bestemt historisk. Som man har set, sker afretningen under stor voldsudøvelse og under tilføjelse af stor lidelse. Det var alt andet end let at tæmme rovdyret menneske.

Det ligger derfor Nietzsche fjernt at kritisere afretningen i sig selv, sådan som det kunne være nærliggende at tolke ham. Der er nemlig ikke tale om, at kulturen og dens tæmning finder sig konfronteret med en naturtilstand der bygger på fri udfoldelse, en "fri" naturtilstand. Nietzsche begår sig ikke i en kulturkritik, der vil tilbage til naturen; han agter ikke grundlæggende kulturen som noget skidt der perverterer naturen. Ej heller giver han udtryk for en kulturpessimisme sådan som man finder tendenser til hos Heidegger, Adorno og Horkheimer. Nietzsche forestiller sig ikke, at kulturen med en indre logik udvikler sig mod en større knægtelse og underkuelse af naturen, herunder af den indre menneskelige natur. Hans vurdering af den tæmning der finder sted i kulturen, er derfor alt andet end entydig. Og det hænger sammen med at genealogien ikke er en historieskrivning der taler fra et entydigt og veldefineret sted. Vurderingen af den dressur der finder sted i kulturen, afhænger derfor af de perspektiver man evner at anlægge på den. Men også af de sammenhænge man evner at tolke kulturen og dens beherskelse ind $\mathrm{i}$ - hvilke høje mål man evner at kunne give kulturen og bruge beherskelsen til, den beherskelse af naturen der oparbejdes i kulturen.

Når kulturen i det forhistoriske perspektiv betragtes som beherskelse, lader det en vakant plads stå tilbage. Det bliver et spørgsmål hvad der hersker i kulturen, når den udfolder sig som beherskelse. Her kræver det forhistoriske perspektiv en opfyldning. Og denne bestemte opfyldning gives det forhistoriske perspektiv i historien. Her bliver de reaktive kræfter i stadig stigende grad herskende; historien skildrer de reaktive kræfters sejr. Kulturens aktivitet, den aktive fortrængning af naturen, stiller historien i de reaktive kræfters tjeneste. Den selvbeherskelse som mennesket har lært sig, gør det nemlig velegnet til senere at blive behersket af ressentiments-kulturen. Og først derved bliver 
den beherskelse der finder sted i kulturen, for en historisk betragtning, tvivlsom. Historien knægter naturen på en måde som ikke lader sig retfærdiggøre ved at henvise til højere formål. Historien indebarer kulturens degeneration.

I historien optræder kulturen altså i en degenereret skikkelse. I den bliver rovdyret menneske endegyldigt behersket og underkuet. Men resultatet er et misfoster - "et tamt og civiliseret husdyr" som Nietzsche skriver (I. afh., afs. 11). Dette husdyr ledes ved sig selv og lider ved at der er som det er "vi lider af mennesket" (ibid.). - Men Nietzsche antyder i begyndelse af II. afhandling også den mulighed at kulturen kan gives en anden retning i en tid der følger efter vores historie: $i$ en efter- eller post-histoire. Han taler her om kulturens forhistoriske arbejde og siger så: "Stiller vi os ved enden af denne uhyre proces - dér hvor træet endelig viser sine modne frugter, hvor socialiteten og sædernes sædelighed endelig bringer for dagen til hvad de kun var midlet -, så finder vi som den rigeste frugt på træet det suverane individ der kun ligner sig selv, der er løsgjort fra sædernes sædelighed, det autonome oversædelige individ, kort sagt et menneske der besidder en egen uafhængig lang vilje og er i stand til at love" (II. afh., afs. 2).

Den afretning der finder sted i kulturen, er altså for Nietzsche ikke, som man så ofte karakteriserer den, bare noget der overgår mennesket. Den er ikke blot noget passivt, men den er frugten af en aktivitet. I den overskrider man den umiddelbare naturs aktivitet gennem aktiv beherskelse. Denne beherskelse af den ydre og den indre natur, af omgivelserne og af selvet, kan også som tidligere antydet ses som en frigorelsesproces. Men her er frihed ikke noget man har; den er hverken en genstand eller en egenskab man besidder. Frihed er noget man må skabe sig gennem en stadig aktivitet, et stadigt arbejde. For Nietzsche er det således pga. ordets nutidige brug misvisende at tale om frihed i og for sig; det er bedre at tale om frigørelse: om hvordan vi gør os fri fra noget og overskrider en umiddelbart given socialitet gennem en aktiv indsats.

Men Nietzsche fastholder derudover den mulighed at beherskelsen af og frigørelsen fra naturen under enten sædernes sædlighed eller ressentimentets morallov senere vil kunne ske under en anden 'lovgivende' magt. Han skriver eksempelvis: "Retfærdigheden ender som alle gode ting på jorden med at ophave sig selv" (II. afh., afs. 11), og han nævner derfor også et vist "hensides retten" (Jenseits des Rechts). Baggrunden for dette er, at kulturen og den beherskelse af den ydre og indre natur konstruerer et produkt, det kulturelle menneske, og dette produkt har i sin hidtidige historie være underkastet ydre lovgivning. Men nu øjner Nietzsche den chance at den evne til beherskelse og frigørelse som kulturen har lært mennesket, kan vendes mod al ydre tvang. Da vil det menneske der er kultiveret, kunne beherske og frigøre sig fra alle ydre former for tvang, og hermed er muligheden skabt for at naturens og den ydre 
lovgivnings beherskelse af mennesket kan overskrides og indgå i dets 'selvlovgivning', i det autonome individs bestemmelse over sig selv. På den måde kan den aktive beherskelses hidtidige underordning af mennesket under sædernes sædelighed og ressentimentets reaktivitet forandres. Den vil ifølge Nietzsche kunne afløses af eller omtolkes til en underordning under en ny form for aktivitet: under et kultiveret menneskes mulige nye 'lovgivning' eller værdisættelse for sig selv og andre. Det menneske som kulturen har lært beherskelse og selvbeherskelse, har nemlig allerede lært meget: det har lært at holde løfter, at lovgive, at sætte værdier for sig selv, at vise ansvarlighed og have udsyn til fremtiden. Således har kulturen frembragt et produkt der kan overskride, eller i hvert fald har muligheden i sig for at overskride, de hidtidige kulturformer; det vil selv kunne sætte nye formål. Hvilken karakter et sådan fremtidigt eller post-historisk produkt kan få, lader Nietzsche imidlertid i høj grad stå åbent, dog gerne under etiketten "Das Übermensch", altså som noget det overskrider mennesket sådan som man hidtil har kendt det. Det er nemlig et uudfoldet produkt hvis indhold og muligheder endnu ikke har vist sig og hvis karakter man ikke på forhånd kan foreskrive. Det må netop være umuligt på forhånd at lovgive for et individ, der er bestemt som både autonomt og suverænt. Det ville være at moralisere. Man kan kun forberede og fremme sådanne individers komme; deres egen lovgivning må de selv sørge for.

Dette betyder at genealogiens perspektiv også bestemmes af muligheden for sådan en ny transformation af kulturen. Sædvane- og ressentimentskulturerne kan dermed betragtes kritisk ud fra muligheden for en sådan anden kultur. Men denne nye mulighed for kultur er ikke positivt tilstede. Og det betyder at genealogen må betragte vores virkelighed og vores historie under en synsvinkel hvis karakter ikke kan stå helt klart for den selv. Genealogien kan ikke fuldstændigt redegøre for hvilken normativitet der tillader den at henvise til en endnu ikke given virkelighed. Men så meget er i hvert fald sikkert, at der med henvisningen til individets foregrebne autonome selvlovgivning ikke bare er tale om at følge naturlige og vilkårlige indskydelser i den sædvanlige betydning af ordene. Gennem den forhistoriske kulturelle opdragelse tænker Nietzsche sig, at der er sket en transformation af menneskets naturlige indskydelser og tilbøjeligheder der giver dem en mere forpligtende og blivende karakter. Mennesket er blevet et mere socialt væsen igennem den kulturelle opdragelse. 


\section{Inderliggørelsen og den dårlige samvittighed}

Som nævnt er vores historiske eller faktiske udgave af samvittigheden præget af ressentimentets omtydning af den forhistoriske samvittighed, og denne omtydning har sin forudsætning $\mathrm{i}$ at destruktiviteten efterhånden er blevet inderliggjort. Sædvanesamfundets tidligere eksterne aktivitet og den medhørende destruktive vold er blevet hæmmet, og denne hæmning fører ifølge Nietzsche til at de indvendiggøres. Aktiviteten optræder derefter som en frustration og destruktiviteten som indre nag og smerte. Og om det skred der sker her, bruger Nietzsche så stærke ord som at det er "den mest dybtgående af alle ændringer". I hans "Hypotese om den dårlige samvittigheds oprindelse" (Hypothese über den Ursprung des schlechten Gewissens) udtrykkes dette tydeligt idet han her fremstiller den dårlige samvittighed "som den svære sygdom mennesket nødvendigvis måtte pådrage sig under trykket af den mest dybtgående af alle ændringer, som det overhovedet har oplevet, og som indtraf da det endegyldigt fandt sig indesluttet i samfundets og fredens tryllekreds [den Bann der Gesellschaft und des Friedens]" (II. afh., afs. 16; fremhævelse tilføjet).

Den tidlige, rudimentære socialitet er præget af eksternalitet: alt opleves som udadrettet udveksling, og denne udadrettede aktivitet følges op af en medfølgende udadrettet destruktivitet. Man har set den skildret som en tilstand af kamp, vold, skyldighed og en udligning der udmærket kunne ske gennem påført lidelse. Denne umiddelbare eksterne eller udadrettede udveksling underbindes imidlertid hvor den indlejres i en samfundsmassighed. Det er i den anledning Nietzsche i citatet taler om "Bann der Gesellschaft". Udvekslingen bliver styret, lagt i rammer, og en tilstand af fred indstiftes. Dette sker gennem lovens ydre påbud, en ydre tvang i forhold til de parter der er involverede i udvekslingen. Hvad der før kunne vendes udad, må nu vendes indad.

Og netop her er den dårlige samvittigheds arnested. Den opstår idet den udadrettede aktivitet og dens destruktivitet rettes indad. Aktiviteten rettes destruktivt mod den der udøver den. Den dårlige samvittighed er altså en omdirigeret, en indadrettet destruktiv aktivitet: "Fjendskabet, grusomheden, lysten ved at overfalde, ved at afveksle, ved at ødelægge - alt dette vender sig imod indehaverne af sådanne instinkter: det er oprindelsen til »den dårlige samvittighed «" (II. afh., afs. 16).

Men som tidligere omtalt er den ydre destruktive aktivitet for Nietzsche også en udfoldelses- og dermed en frigørelsesproces. Igennem sin aktivitet sætter den enkelte sig igennem over for de andre og over for sine omgivelser. Han skaber rum for sig selv igennem sin aktivitet. Men når den ydre aktivitet underbindes, så underbindes også den aktive frigørelsesproces, således at den gøres statisk. Vendt indad bliver den både statisk og skjult: "et uhyre kvantum frihed [trykkes, S.R.] ud af verden, i det mindste ud af syne og gøres ligesom 
latent. Dette latent-gjorte [latent gemachte] friheds-instinkt er trængt indad [...] og slipper sig til sidst kun løs på sig selv: dét og kun det er fra første færd den dårlige samvittighed" (II. afh., afs. 17). Den dårlige samvittighed er altså en oprindeligt frigørende og aktiv destruktivitet der omdirigeres og arbejder sig af mod og på sig selv. Den bliver igennem subjektets indre arbejde med sig selv en indre egenskab ved det. Denne egenskab der opstår gennem subjektets arbejde med sig selv, rammer det som dårlig samvittighed.

\section{Statsdannelsen og den påtvungne passivitet}

Det er altså kulturens ydre tvang, der ifølge Nietzsche underbinder den ydre aktivitet og tvinger den til at vende sig indad. Denne ydre tvang findes endnu ikke i den rudimentære socialitet hvori Nietzsche opsøgte straffens, samvittighedens og ansvarlighedens herkomst. Men allerede her så man en begyndende udveksling, et rudimentært skyldighedsforhold og en idé om ækvivalens. Blot er tvangen endnu ikke ekstern i forhold til denne. Der indgår nok elementer af straf og tvang i udvekslingen, men de udgår fra de enheder der indgår i den. De er altså stadigvæk interne led i udvekslingen selv. Vel opdrager og afretter parterne i den rudimentære socialitet til stadighed hinanden, men ingen opfatter sig selv som hævet over at være part i nogen verserende sag. Der findes m.a.o. endnu ingen ekstern instans i forhold til udvekslingen der gør sig gældende i den og påtvinger den en bestemt form.

Det er ifølge Nietzsche først senere i kulturprocessen at individerne påføres en ekstern tvang. Den eksterne tvang - og dermed ophavet til den dårlige samvittighed - gives først hvor der optræder en rudimentar statsdannelse der ændrer den tidlige socialitet til et samfund, til Nietzsches "Gesellschaft". Denne statsdannelsesproces kommer i gang ved at en del af befolkningen eller et fremmed folk sætter sig igennem over for befolkningen som helhed; et herrefolk underkaster sig en befolkning eller erobrer deres land og gør sig således til herre over dem. Her finder en aktiv magtudøvelse sted, og gennem processen installerer herrefolket sig selv som en fremmed overinstans. Herrefolket påbyder dels 'de andre' en fremmed lov, nemlig herrefolkets egen lov, altså en ikke-selvfølgeligt virkende lov, en lov der er ukendt som del af den på forhånd givne sociale udveksling; og dels en påtvungen lov som man ikke kan unddrage sig, men må overtage passivt. Dermed er der tale om en lov der, fordi den er fremmed, tvinger de beherskede til passivitet (jvf. II. afh., afs. 17).

Man kan så spørge, hvorfor Nietzsche begynder at tale om statsdannelse i forbindelse med at en befolkningsgruppe gør sig til herre over andre grupper, gør sig til herrefolket. - Hvorfor er der tale om en rudimentær statsdannelse netop fra det øjeblik? - Så vidt det kan ses fordi der, set fra de underkastedes synsvinkel, hermed er tale om en første begyndende selustandiggorelse 
af autoriteten. Med herrefolket kan magt og autoritet for første gang opleves som noget der selvstændiggør sig i forhold til de umiddelbare personlige relationer og det umiddelbare magtspil mellem folk. Autoriteten og magten kan for første gang opleves som en fremmed magt der står over for individerne. Før var den altid et led i de personlige relationer, en egenskab ved dem. Med herrefolket lægges for første gang fundamentet til et overindividuelt magtorgan.

Det er blevet fremhævet, at når staten dannes og etableres som et ydre påbud, så tvinger det de underordnede til passivitet. De udsættes for en ekstra, ydre repression som de ikke kan frigøre sig fra, og dette påtvinger dem et ekstra mål af passivitet i forhold til den passivitet og reaktivitet som den umiddelbare socialitet påtvinger dem. Dermed bliver passiviteten og reaktiviteten et dominerende træk som efterfølgende vil præge enhver form for aktivitet. Således kommer handlings-undertrykkelses-aspektet til at dominere over handlingsaspektet. Dette er det afgørende skred som sker fra den første rudimentære kultur eller socialitet til den første statsdannelse, og det er et skred som fuldbyrdes idet der installeres en mer-repression. Men heri ligger også at følelserne vinder overhånd over aktiviteten, for følelser er for Nietzsche at forstå som en indadvendt aktivitet. Individernes reaktion på omverdenen udtømmes ikke mere i en aktion; de holder op med at blive 'af-handlet' for i stedet at blive 'følt'. Vores reaktion på omverdenen bliver i stedet for at blive 'ud-ført' 'gennem'- og 'ud-levet' i indre følelser.

\section{Ressentimentets koblinger og inderliggørelsen}

Mer-repressionen og den indadvendthed eller inderliggørelse som den afføder, skaber et problem:-At jeg lider (i min indadvendthed, i min frustration, i min smerte og mit nag). Og det stiller det spørgsmål: - Hvorfor lider jeg? Sådant et spørgsmål gælder retfardiggorelsen af livet, eller måske snarere retfærdiggørelsen af bestemte livsformer. Det kan også kaldes spørgsmålet om meningen med livet: - Hvad er meningen med min eksistens som lidende? Hvordan retfærdiggør jeg en livsform - min egen - som lider? Dette spørgsmål gælder, om man kan efterrationalisere sin tilværelse som lidende. Som tidligere berørt er problemet ikke så meget at mennesket ikke kan udholde lidelsen som sådan. For Nietzsche er mennesket et dyr, der er i stand til at udholde en endda ganske stor lidelse, og endog finde glæde ved det. Men mennesket er kun i stand til at udholde lidelsen hvis den kan retfærdiggøres, hvis det evner at give den en mening.

Nietzsche skriver: "Det oprørende i lidelsen er ikke lidelsen i sig selv, men lidelsens meningsløshed; imidlertid fandtes der hverken for den kristne eller ældre tiders naive menneske en sådan meningslos lidelse" (II. afh., afs. 7). Hermed antydes det at den kristne præst skaber en løsning på det skitserede 
problem. Han retfærdiggør det forhold, at der findes en indadvendt eksistens som lider pga. sin egen opfindsomhed, sin egen evne til at skabe. Den kristne præst giver derved den indadvendte, lidende eksistens en mening. Det gør han ved at koble indadvendtheden med den metafysik som den jødiske præst har skabt. Og derved sker der en kobling af indadvendtheden og moraliseringen. Den kristne præsts genistreg er nemlig ifølge Nietzsche, at han vender den metafysik som den jødiske præstestand har skabt, indad - det er det nye! Herved bliver der tale om en paradoksal retfærdiggørelse, eller en retfærdiggørelse der tager en paradoksal vending. For det lidelsesfulde liv retfærdiggøres hermed ud fra at livet er uretfærdigt for en oververdslig betragtning. Livet er nemlig mangelfuldt set ud fra en oververden. Den kristne præstestand bruger m.a.o. metafysikken til at anklage livet med. Den siger: "Du lider, mit barn, men det er fordi du selv er årsag til din lidelse, det er fordi du ikke lever op til de egentlige værdier." Når der er lidelse i livet, bliver det altså af det kristne præsteskab vendt til en anklage mod livet: livet er uretfærdigt, der er noget galt med det. Efterrationaliserende antager man så: "Gennem lidelsen bøder livet for en grundlæggende fejl; livet må være skyldigt eftersom det lider." Smerten omtolkes altså til en straf (jvf. den kristne forestilling om syndefaldet).

Gennem det kristne præsteskabs omtolkning sættes en slags kortslutning i værk, og i denne kortslutning finder en inderliggorelse (Verinnerlichung) af livet sted. Hele vores liv inderliggøres idet "hele den indre verden, oprindeligt tynd som mellem to hinder, har videt sig ud til alle sider, har fået dybte, bredde, højde, efterhånden som menneskets udladning udadtil er blevet hammet' (II. afh., afs. 16). Livet retfærdiggøres altså idet det arbejder sig af imod en metafysik eller en lov der er rent indre. Livet in toto præges herefter af den indre lov. Kafkas In der Strafkolonie kan læses som en udmærket illustration af dette forhold. Den indre lov eller moraliteten rister konkret sit navn i livet idet den optræder som afstraffelsesmaskine. På den måde opstår en afklaring, en afklaret bevidsthed om at her sker retfærdigheden fyldest. Hvor overvirkeligheden på denne måde indristes i det inderliggjorte liv, markerer den tidligere aktive destruktivitet sig stadigvæk både hos Nietzsche og Kafka. Nietzsche siger et sted, at den kristne elsker livet på samme måde som rovfuglen elsker lammet: som sart, lemlastet, blødende og doende. Selv igennem sin kærlighed (til højere værdier) elsker den kristne livet, blot destruktivt; han elsker det idet han lemlæster det. Derfor optræder han selv som Guds lam. Og den kristne præstestand har hermed omdirigeret ressentimentets retning. Vendingen gennemføres dog $i$ to tempi: Den jødiske præst ændrer først ressentimentet fra at gælde reaktivitet og passivitet til at være rettet mod aktiviteten, det aristotratiske samfund og dets forskelssættelse; den kristne præst ændrer så ressentimentet og dets nej fra at være udadrettet til at være indadrettet. 
Igennem denne ændring af ressentimentets retning til at gælde det endeløse og uløselige arbejde med os selv opstår den dårlige samvittighed. Den er nemlig kendetegnet ved at den aldrig er i stand til at indløse sin skyldighed, og derfor må den altid skylde nogen noget. Når den dårlige samvittighed opstår, sker det idet smerten mangedobles ved at aktiviteten indadvendes, og idet smerten inderliggøres ved at ressentimentets retning ændres. Herefter identificerer vi os under indflydelse af den kristne præst med smerten. Men $i$ al denne tale om smerten i den dårlige samvittighed fastholder Nietzsche at når smerten påføres i den dårlige samvittighed, har den fortsat den samme funktion som hos herrefolket og i det primære ressentiment. Også i den dårlige samvittighed påføres smerten for at gøre nogen glade. Den gør den glad der påfører den. Man kan i forlængelse heraf forskyde betoningen i det førnævnte citat: den kristne elsker livet som rovfuglen elsker lammet. I den dårlige samvittighed elsker den kristne sig selv som lemlæstet, blødende og døende. Derfor kan den dårlige samvittighed også virke revitaliserende.

Alt dette er processer, der fortætter sig i den fortidige historie, og hvis ingredienser vi $i$ vor nutidige situation er $i$ stand til at gennemskue. De har deres herkomst i en kamp mod herrefolkene. Allerede den jødiske præstestand søger ved at skabe moraliteten og give den metafysisk gyldighed at hævde sig over for babylonerne og dernæst over for romerne. Og når den kristne præstestand konstruerer inderliggørelsen i senmiddelalderen og reformationen, søger den at reintegrere og overvinde tendenser i renæssancen i retning af udvendiggørelse og re-aristokratisering. Slutpunktet på den første af disse forløb kan fastlægges til 65 e.Kr. hvor bruddet mellem jødedom og kristendom bliver til, mens den anden historie forløber frem til ca. 1600 hvor reformationens følger bliver mærkbare. Men den har også rødder langt tilbage i forhistorien før aristokratiets og herrefolkenes opkomst, og den strækker sig derfor over et uhyre langt forløb.

Inden for de givne rammer vil det imidlertid fører alt for vidt at følge denne lange forhistorie mere detaljeret. Derfor vil jeg umiddelbart nøjes med at henvise til min kommende udgivelse, Metafysikkens evindelig genkomst, hvor jeg behadler hele Zur Genealogie der Moral mere indgående. I min disputats Sameksistens uden common sense, beskæftiger jeg mig i Del III med afsæt i M. Foucault ligeledes med den dårlige samvittighed, men her under en mere nutidig synsvinkel. Just hvor Nietzsche afbryder sit studie af den dårlige samvittigheds genealogi, som nævnt ved slutningen af reformationstiden, tager Foucault nemlig sit afsæt i Overvågning og straf (Surveiller et punir). Men han ændrer dog perspektivet i forhold til Nietzsche, idet han søger at vise hvordan en mere aktuel form for uendeliggjort dårlig samvittighed er blevet til som en skyggeside af den disciplineringsproces der har præget de moderne vestlige samfund. 
Nietzsche undersøgelse af den dårlige samvittigheds herkomst samt dens sammenhæng med ansvarlighed, skyld og straf er imidlertid ikke blot en foreteelse, der søger at bekræfte en uoverstigelig historisk afstand til fortidens forlængst glemte synder. Kongenialt med Foucaults undersøgelse af den moderne disciplins herkomst sådan som den fremstår i forbindelse med fængslets fødsel, er Nietzsches genealogiske bestræbelser i Zur Genealogie der Moral et forsøg på at beskrive hvordan en problematik efterhånden er blevet til der stadig, under nye former ganske vist, gør sig gældende i nutiden. Men konfrontationen med den historiske fremmedhed er samtidig et forsøg på at vise hvordan der "bagved tingene", også i tilfældet med ansvarligheden og den dårlige samvittighed, "er helt andre ting: ikke deres essentielle og udaterede hemmelighed, men den hemmelighed at de er uden essens, eller at deres essens er blevet konstrueret stykke for stykke, ud fra figurer som var fremmede for denne. - Fornuften? - Den er født på helt igennem fornuftig vis af tilfældet." (Foucault: "Nietzsche, genealogien, historien", s. 87). Ved at konfrontere os med sådan en fremmedhed søger Nietzsche at forskyde os i forhold den dårlige samvittighed der stadig præger vores selvforhold, der stadig gør sig gældende i vores forsøg på at fastholde en ansvarlighed. Og således bibeholder han en klassisk filosofisk dyd, nemlig radikalt at sætte spørgsmålstegn ved vores selvfølgeligheder.

\section{Litteraturliste}

Foucault, M.: ([1975] 1977) Overvågning og straf, København.

Foucault, M.: ([1971]1983) “Nietzsche, genealogien historien”, i Gosvig, S. (red): Epistemologi, København.

Nietzsche, F.: ([1971]) Morgenröte, Berlin.

Nietzsche, F.: ([1968] 1993) Moralens genealogi, Frederiksberg.

Raffnsøe, S.:(2001) Sameksistens uden common sense, København. 